OPEN ACCESS

Edited by:

Renato Anghinah,

University of São Paulo

School of Medicine, Brazil

Reviewed by:

Firas H. Kobeissy,

University of Florida, USA

Elham Abbasloo,

Kerman Physiology Research Center,

Iran

*Correspondence:

Batool F. Kirmani

Batool.kirmani@BSWHealth.org

Specialty section:

This article was submitted to

Neurotrauma,

a section of the journal

Frontiers in Neurology

Received: 27 August 2015

Accepted: 29 February 2016

Published: 22 March 2016

Citation:

Kirmani BF, Robinson DM, Fonkem E,

Graf $K$ and Huang JH (2016) Role of

Anticonvulsants in the Management

of Posttraumatic Epilepsy.

Front. Neurol. 7:32.

doi: 10.3389/fneur.2016.00032

\section{Role of Anticonvulsants in the Management of Posttraumatic Epilepsy}

\author{
Batool F. Kirmani ${ }^{1 \star}$, Diana Mungall Robinson ${ }^{2}$, Ekokobe Fonkem ${ }^{3}$, Kevin Graf $^{3}$ and \\ Jason H. Huang ${ }^{4}$
}

${ }^{1}$ Epilepsy Center, Department of Neurology, Baylor Scott \& White Health Neuroscience Institute, Texas A\&M Health Science Center College of Medicine, Temple, TX, USA, ${ }^{2}$ Department of Psychiatry, University of Virginia Medical Center, Charlottesville, VA, USA, ${ }^{3}$ Division of Neuro-oncology, Department of Neurosurgery, Baylor Scott \& White Health Neuroscience Institute, Texas A\&M Health Science Center College of Medicine, Temple, TX, USA, ${ }^{4}$ Department of Neurosurgery, Baylor Scott \& White Health Neuroscience Institute, Texas A\&M Health Science Center College of Medicine, Temple, TX, USA

Posttraumatic seizures (PTS) have been recognized as a major complication of traumatic brain injury (TBI). The annual incidence of TBI in the United States is 1.7 million. The role of anticonvulsants in the treatment of posttraumatic epilepsy (PTE) remains uncertain. Based on current studies, however, anticonvulsants have been shown to reduce early PTS occurring within the first 7 days, but little to no benefits have been shown in late PTS occurring after 7 days. In this paper, we provide a mini review of the role of anticonvulsants and current advances in the management of PTE.

Keywords: posttraumatic seizures, traumatic brain injury, epilepsy, anticonvulsants, management

\section{POSTTRAUMATIC EPILEPSY}

Posttraumatic epilepsy (PTE) due to traumatic brain injury (TBI) has many causes, including wartime combat, vehicle accidents, work-related injuries, and sports injuries. Wartime combat injuries, especially blast injuries and penetrating head injuries (PTI), have shown to increase the risk of seizures, as that of blast models of TBI (1-4). The annual incidence of TBI is estimated to be 1.7 million in the United States, and seizures have been recognized as one of the major complications of this condition (5). The incidence of PTE was described by Annegers and colleagues who conducted a retrospective study in order to identify the characteristics of brain injuries that are associated with the development of seizures for 50 years. The results showed that the severity of the injury was correlated with the interval during which the risk of seizures was increased, even after more than 20 years post injury (6). The other study of interest was the Vietnam Head Injury Study (VHIS) that was a prospective, longitudinal follow-up of 1,221 Vietnam War Veterans who had PTI. The prevalence of PTE in this cohort was 45-53\%. Patients with PTI carry a high risk of PTE even for decades; so, long-term medical follow-up is required (7). Similarly, the prospective study by Salazar and colleagues showed that seizure frequency in the first year predicted future severity of seizures. A higher seizure frequency was seen in the first year and was also associated with subjects having a longer duration of epilepsy and persistent seizures (8).

\section{ROLE OF ANTICONVULSANTS IN THE MANAGEMENT OF POSTTRAUMATIC EPILEPSY}

The seizures after head injury result in secondary brain damage, which involves increased intracranial pressure, increased metabolic brain demands posthead injury, and excessive release of neurotransmitters, 
which result in further complicating the existing damage. The main goal of anticonvulsants is to minimize the brain damage by preventing early seizures (9).

The other role of anticonvulsants apart from antiseizure activity is the neuroprotective effect, which has been demonstrated in animal models. Phenytoin, which is still considered as an agent of choice, has been shown to have neuroprotective properties in animal models. Vartanian and colleagues showed that phenytoin has been linked with decreased neuronal damage in neonatal rats following hypoxia (10). Another study by Tasker and colleagues showed similar results in rat hippocampal structures (11). Researchers suggested that neuroprotective effects were related to a blockage of voltage-dependent sodium channels during hypoxia, which decreased the spread of calcium-induced neurotoxicity following hypoxic brain injury $(10,11)$.

Posttraumatic seizures (PTS) are divided into two subgroups, early and late PTS. Early seizures occur within the first 7 days after brain injury, and late seizures occur after 7 days of injury. These definitions are important in terms of management and predicting prognosis of PTE (12).

The prospective randomized trials did not show promising results of the role anticonvulsants in the management of PTS. The randomized clinical trials are summarized in Table 1. No significant differences were seen in the treatment versus the nontreatment groups (13-20). Summary of selected non-randomized trials for posttraumatic seizure prevention was shown in Table 2, which also did not show a significant difference between groups (21-28).

Temkin and colleagues showed that phenytoin was considered effective in preventing provoked seizures and promising at preventing unprovoked seizures. Carbamazepine was considered effective in preventing provoked seizures after TBI, although its status was considered uncertain in preventing unprovoked seizures. Phenobarbital was considered promising at preventing provoked seizures and uncertain at preventing unprovoked seizures. Finally, the combination of phenytoin and phenobarbital was considered promising to prevent provoked and unprovoked seizures. It was also shown that provoked seizures showed promising results, but for unprovoked seizures, no drugs were shown to be effective. AEDs prescribed to prevent epileptogenesis should be avoided until clinical trials have found a drug for this purpose (29). Similarly, Chang and Lowenstein conducted a literature review of the evidence of AED prophylaxis in patients with severe TBI in order to guide better practice recommendations. Patients given phenytoin prophylaxis compared to controls had a significantly lower risk of early PTS in

TABLE 1 | Summary of selected randomized controlled trials (RCT) for posttraumatic seizure prevention.

\begin{tabular}{|c|c|c|c|c|}
\hline Reference & Study design & $\begin{array}{l}\text { Number of patients } \\
\text { randomized }(N)\end{array}$ & Methods & Outcome \\
\hline $\begin{array}{l}\text { Dikmen } \\
\text { et al. (13) }\end{array}$ & $\mathrm{RCT}$ & 124 & $\begin{array}{l}\text { Phenytoin versus placebo } \\
\text { Patients were randomized to receive either PHT or placebo for } \\
1 \text { year and observed one more year without medication }\end{array}$ & $\begin{array}{l}\text { No significant differences seen in } \\
\text { neuropsychological examinations in } 1 \text { year } \\
\text { between the } 2 \text { groups }\end{array}$ \\
\hline $\begin{array}{l}\text { Temkin } \\
\text { et al. (14) }\end{array}$ & $\mathrm{RCT}$ & 123 & $\begin{array}{l}\text { Phenytoin versus placebo } \\
\text { Treatment was started within } 24 \text { h of injury for } 1 \text { year and then } \\
2 \text { groups were followed for } 2 \text { years }\end{array}$ & $\begin{array}{l}\text { Early seizures: improvement seen in the } \\
\text { PHT GROUP } \\
\text { Late seizures: no difference between the } \\
2 \text { groups }\end{array}$ \\
\hline $\begin{array}{l}\text { Young et al. } \\
\text { (15) }\end{array}$ & $\mathrm{RCT}$ & 244 & $\begin{array}{l}\text { Phenytoin versus placebo } \\
\text { Treatment was started within } 24 \text { h of injury }\end{array}$ & $\begin{array}{l}\text { Early seizures: no difference between the } \\
2 \text { groups } \\
\text { Late seizures: study was not designed to } \\
\text { determine late seizure outcome }\end{array}$ \\
\hline $\begin{array}{l}\text { Young et al. } \\
\text { (16) }\end{array}$ & $\mathrm{RCT}$ & 179 & $\begin{array}{l}\text { Phenytoin versus placebo } \\
\text { Treatment was started within } 24 \text { h of injury and } 2 \text { groups were } \\
\text { followed for } 18 \text { months to determine late seizure outcome }\end{array}$ & $\begin{array}{l}\text { Early seizures: study was not designed to } \\
\text { determine early seizure outcome } \\
\text { Late seizures: no difference between the } \\
2 \text { groups }\end{array}$ \\
\hline $\begin{array}{l}\text { McQueen } \\
\text { et al. (17) }\end{array}$ & $\mathrm{RCT}$ & 164 & $\begin{array}{l}\text { Phenytoin versus placebo } \\
\text { Two groups were followed for } 2 \text { years } \\
\text { Occurrence of seizures was used as outcome measure }\end{array}$ & $\begin{array}{l}\text { Early seizures: study was not designed to } \\
\text { determine early seizure outcome } \\
\text { Late seizures: no difference between the } \\
2 \text { groups }\end{array}$ \\
\hline $\begin{array}{l}\text { Szaflarski } \\
\text { et al. (18) }\end{array}$ & $\mathrm{RCT}$ & 52 & $\begin{array}{l}\text { Phenytoin versus levetiracetam } \\
\text { Treatment was started within } 24 \text { h of injury between the } \\
2 \text { groups }\end{array}$ & $\begin{array}{l}\text { Early seizures: no difference between the } \\
2 \text { groups } \\
\text { Late seizures: study was not designed to } \\
\text { determine late seizure outcome }\end{array}$ \\
\hline $\begin{array}{l}\text { Temkin } \\
\text { et al. (19) }\end{array}$ & $\mathrm{RCT}$ & 379 & $\begin{array}{l}\text { Phenytoin for } 1 \text { week versus valproate for } 1 \text { month versus } \\
\text { valproate for } 6 \text { months } \\
\text { Treatment was started within } 24 \text { h of injury } \\
\text { Follow-up of these groups continued for } 2 \text { years }\end{array}$ & $\begin{array}{l}\text { Early seizures: no difference among } \\
3 \text { groups } \\
\text { Early seizures: no difference among } \\
3 \text { groups }\end{array}$ \\
\hline Manaka (20) & $\mathrm{RCT}$ & 191 & $\begin{array}{l}\text { Phenobarbital versus no treatment } \\
\text { Treatment was started within } 4 \text { weeks post head injury } \\
\text { They received full dose for } 2 \text { years and tapered off in third year } \\
\text { Follow-up in } 5 \text { years }\end{array}$ & $\begin{array}{l}\text { Early seizures: study was not designed to } \\
\text { determine early seizure outcome } \\
\text { Late seizures: no difference among } \\
3 \text { groups }\end{array}$ \\
\hline
\end{tabular}


TABLE 2 | Summary of selected non-randomized trials for posttraumatic seizure prevention.

\begin{tabular}{|c|c|c|c|c|}
\hline Reference & Study design & $\begin{array}{l}\text { Number of patients } \\
\text { randomized }(N)\end{array}$ & Methods & Outcome \\
\hline $\begin{array}{l}\text { Servit and } \\
\text { Musil (21) }\end{array}$ & Non-RCT & 167 & $\begin{array}{l}\text { Treatment group }(n=143) \text { were administered } \\
\text { phenytoin or phenobarbital } \\
\text { Control group }(n=24) \text { where conventional } \\
\text { treatment was used } \\
\text { Duration: } 2 \text { years }\end{array}$ & $\begin{array}{l}\text { Early seizures: not applicable } \\
\text { Late seizures: } 25 \% \text { in the control group and } 2.1 \% \\
\text { in the treatment group }\end{array}$ \\
\hline Inaba et al. (22) & $\begin{array}{l}\text { Prospective } \\
\text { controlled trial }\end{array}$ & 813 & $\begin{array}{l}\text { Participants were administered either } \\
\text { levetiracetam or phenytoin for } 7 \text { days }\end{array}$ & $\begin{array}{l}\text { Early seizures: no difference between the } 2 \text { groups } \\
\text { Late seizures: not applicable }\end{array}$ \\
\hline $\begin{array}{l}\text { Kruer et al. } \\
\text { (23) }\end{array}$ & $\begin{array}{l}\text { Retrospective } \\
\text { cohort }\end{array}$ & 109 & $\begin{array}{l}\text { Retrospective review of patients who received } \\
\text { levetiracetam or phenytoin }\end{array}$ & $\begin{array}{l}\text { Early seizures: no difference between the } 2 \text { groups } \\
\text { Late seizures: not applicable }\end{array}$ \\
\hline $\begin{array}{l}\text { Gabriel and } \\
\text { Rowe (24) }\end{array}$ & Cohort & 19 & $\begin{array}{l}\text { Participants were divided based on levetiracetam } \\
\text { and phenytoin prophylaxis } \\
\text { Follow-up interview conducted to assess seizure } \\
\text { outcome }\end{array}$ & $\begin{array}{l}\text { Early seizures: no difference between the } 2 \text { groups } \\
\text { Late seizures: no difference between the } 2 \text { groups }\end{array}$ \\
\hline $\begin{array}{l}\text { Jones et al. } \\
\text { (25) }\end{array}$ & Cohort & 27 & $\begin{array}{l}\text { Phenytoin versus levetiracetam administered } \\
\text { during first } 24 \mathrm{~h} \text { post severe TBI }\end{array}$ & $\begin{array}{l}\text { Early seizures: no difference between the } 2 \text { groups } \\
\text { Late seizures: not applicable }\end{array}$ \\
\hline $\begin{array}{l}\text { Bhullar et al. } \\
\text { (26) }\end{array}$ & Case-control & 93 & $\begin{array}{l}\text { Phenytoin versus no treatment to determine } \\
\text { occurrence of early seizures }\end{array}$ & $\begin{array}{l}\text { Early seizures: no difference between the } 2 \text { groups } \\
\text { Late seizures: not applicable }\end{array}$ \\
\hline $\begin{array}{l}\text { Formisano } \\
\text { et al. ( } 27)\end{array}$ & $\begin{array}{l}\text { Retrospective } \\
\text { and prospective }\end{array}$ & 137 & $\begin{array}{l}\text { Anticonvulsants versus no treatment } \\
\text { Study 1: prospective } \\
\text { Study 2: retrospective }\end{array}$ & $\begin{array}{l}\text { Study } 1 \text { - No difference between the } 2 \text { groups } \\
\text { Study } 2 \text { - Late seizures higher in the treated group }\end{array}$ \\
\hline $\begin{array}{l}\text { Watson et al. } \\
\text { (28) }\end{array}$ & Cohort & 404 & $\begin{array}{l}\text { Glucocorticoids administered within } 1 \text { day versus } \\
\text { no glucocorticoids }\end{array}$ & $\begin{array}{l}\text { Early seizures: not applicable } \\
\text { Late seizures: no difference between the } 2 \text { groups }\end{array}$ \\
\hline
\end{tabular}

pooled class I studies. There were no significant differences in the risk of late PTS patients receiving phenytoin, carbamazepine, or valproate prophylaxis versus controls in pooled class I and class II studies. In these studies, adverse effects were frequent, but mild and serum AED levels were suboptimal. The authors concluded that phenytoin prophylaxis is effective in decreasing the risk of early PTS in adult patients with severe TBI. However, late PTS are not decreased by AED prophylaxis (30). Current guidelines issued by the Brain Trauma Foundation and the American Academy of Neurology (AAN) for the management of severe TBI recommend seizure prophylaxis only for 7 days post injury. Phenytoin still remains the desired treatment because it has been extensively studied and there is proven evidence of its efficacy. The other antiepileptic agents, such as phenobarbital, valproate, and carbamazepine, have gone through limited trials as compared to phenytoin and their adverse effect profiles and pharmacodynamics properties still make phenytoin the desired antiepileptic for early prophylaxis of PTS (30).

The new anticonvulsants were favored over the older agents because of their unique pharmacokinetic properties, fewer serious side effects, and fewer drug-drug interactions (31). A second generation anticonvulsant that has generated particular interest is levetiracetam (23). Jones and colleagues conducted a retrospective study, which showed that levetiracetam can be used as an alternative to phenytoin, but the study was limited due to a small sample size (25). Szaflarski and colleagues conducted the first prospective randomized comparative trial of intravenous levetiracetam versus phenytoin for seizure prophylaxis in the neurointensive care unit setting, which showed that levetiracetam can be used as an alternative to phenytoin for seizure prophylaxis in the neuroscience intensive care setting. This study had limitations, including a small sample size and a lack of data reported on the concomitant use of sedating agents for induction of pharmacologically-induced coma (18). Kirmani and colleagues also conducted a literature review on the role of intravenous levetiracetam in seizure prophylaxis of severe TBI patients, which showed that levetiracetam can be used as an option in acute PTS (32). Gabapentin (GBP) is another anticonvulsant that acts at the $\alpha 2 \delta$ - 1 submit of the L-type calcium channel. It has been shown that chronic administration of GBP after cortical injury is antiepileptogenic in the undercut model of PTE. The results suggest that it may have a neuroprotective effect and may also decrease excitatory synapse formation. These results suggest the potential use of GBP as an anticonvulsant following TBI (33). A meta-analysis by Zafar and colleagues also concluded that there is no particular drug that is superior in preventing early seizures (34).

Wroblewski and Joseph reported 10 case studies of TBI patients treated with intramuscular midazolam for acute seizure cessation after other benzodiazepine drugs had failed. Slight to moderate sedation was the only reported side effect. The study was limited due to small sample size and was conducted to treat rather than prevent PTS (35).

The role of anticonvulsants in early PTS seems favorable as compared to late PTS. Anticonvulsants are found to be effective in patients who develop PTE.

Phenytoin remains the most commonly used anticonvulsants, but the side effects do favor the use of newer anticonvulsants, e.g., levetiracetam because of lack of drug-drug interactions and availability in parenteral form. The cognitive side effects and non linear kinetics limit the use in certain patient populations (13). Carbamazepine has shown to be effective but drug-drug interactions and unavailability in parenteral form limits the use 
of this agent. Neurocognitive side effects were also seen in other older anticonvulsants, including Phenobarbital, which may mask the mental status findings in TBI patients because of the sedating effects. Valproate can cause coagulopathy which may result in intracranial hemorrhage $(30,31)$.

Unfortunately, limited scientific data exist, which are specific to PTE with other anticonvulsants, and there is a need for additional controlled randomized clinical trials to explore more options.

\section{NEW DIRECTIONS IN THE MANAGEMENT OF POSTTRAUMATIC EPILEPSY}

The PTE can be differentiated from PTS that are sequelae from TBI. The term PTE signifies recurrent seizure disorder due to TBI or any surgery on the brain (36).

Posttraumatic epilepsy remains a challenge despite new medications that have come in the last decade. We still face problems with effective seizure control. TBI is the most common cause of acquired focal epilepsy (37-40). The model that was commonly used to assess antiepileptogenic interventions is the rostral parasagittal fluid percussion injury model (rpFPI) (41-43). This model helps in mimicking closed head injury by reproducing destructive processes as well as regenerative inflammatory processes (44). This is now considered as an excellent model for PTE (41-44). This model may progress to intractable multifocal epilepsy after a few months post injury (45). Interestingly, this model has shown to represent a severe form of PTE which is not controlled by carbamazepine, valproic acid, and carisbamate $(41,42)$. One study using this model showed mild cooling of

\section{REFERENCES}

1. Kovacs SK, Leonessa F, Ling GS. Blast TBI models, neuropathology, and implications for seizure risk. Front Neurol (2014) 5:47. doi:10.3389/fneur.2014.00047

2. Krisztian KS, Leonessa F, Grimes J, Ling GSF. A neuropathology approach to understanding of explosive blast TBI seizure risk. J Neurol Disord Stroke (2014) 2:1071.

3. Steinmetz S, Tipold A, Löscher W. Epilepsy after head injury in dogs: a natural model of post-traumatic epilepsy. Epilepsia (2013) 54(4):580-8. doi:10.1111/ epi.12071

4. Pitkänen A, McIntosh TK. Animal models of post-traumatic epilepsy. J Neurotrauma (2006) 23(2):241-61. doi:10.1089/neu.2006.23.241

5. Faul M, Xu L, Wald MM, Coronado VG. Traumatic Brain Injury in the United States: Emergency Department Visits, Hospitalizations, and Deaths. Atlanta, GA: Centers for Disease Control and Prevention, National Center for Injury Prevention and Control (2010).

6. Annegers JF, Hauser WA, Coan SP, Rocca WA. A population-based study of seizures after traumatic brain injuries. N Engl J Med (1998) 338:20-4. doi:10.1056/NEJM199801013380104

7. Raymont V, Salazar AM, Lipsky R, Goldman D, Tasick G, Grafman J. Correlates of post-traumatic epilepsy 35 years following combat brain injury. Neurology (2010) 75(3):224-9. doi:10.1212/WNL.0b013e3181e8e6d0

8. Salazar AM, Jabbari B, Vance SC, Grafman J, Amin D, Dillon JD. Epilepsy after penetrating head injury. I. Clinical correlates: a report of the Vietnam Head Injury Study. Neurology (1985) 35:1406-14. doi:10.1212/WNL.35.10.1406

9. Schierhout G, Roberts I. Prophylactic antiepileptic agents after head injury: a systematic review. Neurol Neurosurg Psychiatry (1998) 64:108-12. doi:10.1136/ jnnp.64.1.108

10. Vartanian MG, Cordon JJ, Kupina NC, Schielke GP, Posner A, Raser $\mathrm{KJ}$, et al. Phenytoin pretreatment prevents hypoxic-ischemic brain epileptogenic focus and prevention of recurrent seizures. Based on the above studies, prolonged and mild cooling has been tried in these subgroups of patients and was found to be safe and improve functional recovery (46-49).

The animal model data also show that it is possible to target anti-inflammatory agents that are used for other indications as alternative to anticonvulsants. Progesterone has been shown to have promising effects in several brain injury models (50). The smaller sample size in humans did show some positive results (51, 52). However, the current evidence is insufficient to support the use of progesterone in the management of TBI (53).

\section{CONCLUSION}

Anticonvulsants have proven to be beneficial in the first 7 days post injury. Phenytoin still remains the anticonvulsant of choice because it is widely studied and researched as compared to other anticonvulsants. Levetiracetam seems to be a viable alternative because of its unique pharmacodynamics properties; however, more head-on prospective clinical trials are needed regarding phenytoin in order to prove its efficacy as a first line agent in PTE. Clinical trials are needed to study the efficacy of second and third generation anticonvulsants in the treatment of PTE. Clinical trials are also needed to prove the role of mild selective cooling in patients with PTE.

\section{AUTHOR CONTRIBUTIONS}

All authors listed, have made substantial, direct, and intellectual contribution to the work and approved it for publication. damage in neonatal rats. Brain Res Dev Brain Res (1996) 95(2):169-75. doi:10.1016/0165-3806(96)00073-9

11. Tasker RC, Coyle JT, Vornov JJ. The regional vulnerability to hypoglycemia-induced neurotoxicity in organotypic hippocampal culture: protection by early tetrodotoxin or delayed MK-801. J Neurosci (1992) 12(11):4298-308.

12. Vespa PM, Miller C, McArthur D, Eliseo M, Etchepare M, Hirt D, et al. Nonconvulsive electrographic seizures after traumatic brain injury result in a delayed, prolonged increase in intracranial pressure and metabolic crisis. Crit Care Med (2007) 35:2830-6. doi:10.1097/01.CCM.0000295667.66853.BC

13. Dikmen SS, Temkin NR, Miller B, Machamer J, Winn HR. Neurobehavioral effects of phenytoin prophylaxis of posttraumatic seizures. JAMA (1991) 265(10):1271-7. doi:10.1001/jama.265.10.1271

14. Temkin NR, Dikmen SS, Wilensky AJ, Keihm J, Chabal S, Winn HR. A randomized, double-blind study of phenytoin for the prevention of post-traumatic seizures. N Engl J Med (1990) 323(8):497-502. doi:10.1056/ NEJM199008233230801

15. Young B, Rapp RP, Norton JA, Haack D, Tibbs PA, Bean JR. Failure of prophylactically administered phenytoin to prevent early posttraumatic seizures. J Neurosurg (1983) 58(2):231-5. doi:10.3171/jns.1983.58.2.0236

16. Young B, Rapp RP, Norton JA, Haack D, Tibbs PA, Bean JR. Failure of prophylactically administered phenytoin to prevent late posttraumatic seizures. J Neurosurg (1983) 58(2):236-41. doi:10.3171/jns.1983.58.2.0236

17. McQueen JK, Blackwood DHR, Harris P, Kalbag RM, Johnson AL. Low risk of late post-traumatic seizures following severe head injury: implications for clinical trials of prophylaxis. JNeurol Neurosurg Psychiatry (1983) 46(10):899-904. doi:10.1136/jnnp.46.10.899

18. Szaflarski JP, Sangha KS, Lindsell CJ, Shutter LA. Prospective, randomized, single-blinded comparative trial of intravenous levetiracetam versus phenytoin for seizure prophylaxis. Neurocrit Care (2010) 12:165-72. doi:10.1007/ s12028-009-9304-y 
19. Temkin NR, Dikmen SS, Anderson GD, Wilensky AJ, Holmes MD, Cohen W, et al. Valproate therapy for prevention of posttraumatic seizures: a randomized trial. J Neurosurg (1999) 91(4):593-600. doi:10.3171/jns.1999.91.4.0593

20. Manaka S. Cooperative prospective study on posttraumatic epilepsy: risk factors and the effect of prophylactic anticonvulsant. Jpn J Psychiatry Neurol (1992) 46(2):311-5.

21. Servit Z, Musil F. Prophylactic treatment of posttraumatic epilepsy: results of a long-term follow-up in Czechoslovakia. Epilepsia (1981) 22(3):315-20. doi: 10.1111/j.1528-1157.1981.tb04115.x

22. Inaba K, Menaker J, Branco BC, Gooch J, Okoye OT, Herrold J, et al. A prospective multicenter comparison of levetiracetam versus phenytoin for early posttraumatic seizure prophylaxis. J Trauma Acute Care Surg (2013) 74(3):766-71. doi:10.1097/TA.0b013e3182826e84

23. Kruer RM, Harris LH, Goodwin H, Kornbluth J, Thomas KP, Slater LA, et al. Changing trends in the use of seizure prophylaxis after traumatic brain injury: a shift from phenytoin to levetiracetam. J Crit Care (2013) 28(5):.e9-13. doi:10.1016/j.jcrc.2012.11.020

24. Gabriel WM, Rowe AS. Long-term comparison of GOS-E scores in patients treated with phenytoin or levetiracetam for posttraumatic seizure prophylaxis after traumatic brain injury. Ann Pharmacother (2014) 48(11):1440-4. doi:10.1177/1060028014549013

25. Jones KE, Puccio AM, Harshman KJ, Falcione B, Benedict N, Jankowitz BT, et al. Levetiracetam versus phenytoin for seizure prophylaxis in severe traumatic brain injury. Neurosurg Focus (2008) 25:E3. doi:10.3171/FOC.2008.25.10.E3

26. Bhullar IS, Johnson D, Paul JP, Kerwin AJ, Tepas JJ, Frykberg ER. More harm than good: antiseizure prophylaxis after traumatic brain injury does not decrease seizure rates but may inhibit functional recovery. J Trauma Acute Care Surg (2014) 76(1):54-61. doi:10.1097/TA.0b013e3182aafd15

27. Formisano R, Barba C, Buzzi MG, Newcomb-Fernandez J, Menniti-Ippolito F, Zafonte R, et al. The impact of prophylactic treatment on post-traumatic epilepsy after severe traumatic brain injury. Brain Inj (2007) 21(5):499-504. doi:10.1080/02699050701310994

28. Watson NF, Barber JK, Doherty MJ, Miller JW, Temkin NR. Does glucocorticoid administration prevent late seizures after head injury? Epilepsia (2004) 45(6):690-4. doi:10.1111/j.0013-9580.2004.59403.x

29. Temkin NR. Antiepileptogenesis and seizure prevention trials with antiepileptic drugs: meta-analysis of controlled trials. Epilepsia (2001) 42:515-24. doi:10.1046/j.1528-1157.2001.28900.x

30. Chang BS, Lowenstein DH; Quality Standards Subcommittee of the American Academy of Neurology. Practice parameter: antiepileptic drug prophylaxis in severe traumatic brain injury: report of the Quality Standards Subcommittee of the American Academy of Neurology. Neurology (2003) 60:10-6. doi:10.1212/01.WNL.0000031432.05543.14

31. LaRouche SM. A new look at the second generation antiepileptic drugs: a decade of experience. Neurologist (2007) 13(13):133-9. doi:10.1097/01. nrl.0000256353.14257.7c

32. Kirmani BF, Mungall D, Ling G. Role of intravenous levetiracetam in seizure prophylaxis of severe traumatic brain injury patients. Front Neurol (2013) 4:170. doi:10.3389/fneur.2013.00170

33. Li H, Graber KD, Jin S, McDonald W, Barres BA, Prince DA. Gabapentin decreases epileptiform discharges in a chronic model of neocortical trauma. Neurobiol Dis (2012) 48(3):429-38. doi:10.1016/j.nbd.2012.06.019

34. Zafar SN, Khan AA, Ghauri AA, Shamim MS. Phenytoin versus levetiracetam for seizure prophylaxis after brain injury - a meta analysis. BMC Neurol (2012) 12:30. doi:10.1186/1471-2377-12-30

35. Wroblewski BA, Joseph AB. The use of intramuscular midazolam for acute seizure cessation or behavioral emergencies in patients with traumatic brain injury. Clin Neuropharmacol (1992) 15(1):44-9. doi:10.1097/00002826-199202000-00006

36. Hunt RF, Boychuk JA, Smith BN. Neural circuit mechanisms of post-traumatic epilepsy. Front Cell Neurosci (2013) 7:89. doi:10.3389/fncel.2013.00089

37. Agrawal A, Timothy J, Pandit L, Manju M. Post-traumatic epilepsy: an overview. Clin Neurol Neurosurg (2006) 108:433-9. doi:10.1016/j.clineuro.2005.09.001
38. Eftekhar B, Sahraian MA, Nouralishahi B, Khaji A, Vahabi Z, Ghodsi M, et al. Prognostic factors in the persistence of post-traumatic epilepsy after penetrating head injuries sustained in war. J Neurosurg (2009) 110(2):319-26. doi:10.3171/2008.4.17519

39. Christensen J. Traumatic brain injury: risks of epilepsy and implications for medicolegal assessment. Epilepsia (2012) 53(4):43-7. doi:10.1111/ j.1528-1167.2012.03612.x

40. Frey LC. Epidemiology of post-traumatic epilepsy: a critical review. Epilepsia (2003) 44(10):11-7. doi:10.1046/j.1528-1157.44.s10.4.x

41. Eastman CL, Verley DR, Fender JS, Temkin NR, D’Ambrosio R. ECoG studies of valproate, carbamazepine and halothane in frontal-lobe epilepsy induced by head injury in the rat. Exp Neurol (2010) 224(2):369-88. doi:10.1016/ j.expneurol.2010.04.013

42. Eastman CL, Verley DR, Fender JS, Stewart TH, Nov E, Curia G, et al. Antiepileptic and antiepileptogenic performance of carisbamate after head injury in the rat: blind and randomized studies. J Pharmacol Exp Ther (2011) 336(3):779-90. doi:10.1124/jpet.110.175133

43. Thompson HJ, Lifshitz J, Marklund N, Grady MS, Graham DI, Hovda DA, et al. Lateral fluid percussion brain injury: a 15-year review and evaluation. J Neurotrauma (2005) 22(1):42-75. doi:10.1089/neu.2005.22.42

44. D’Ambrosio R, Eastman CL, Darvas F, Fender JS, Verley DR, Farin FM, et al. Mild passive focal cooling prevents epileptic seizures after head injury in rats. Ann Neurol (2013) 73(2):199-209. doi:10.1002/ana.23764

45. D’Ambrosio R, Fender JS, Fairbanks JP, Simon EA, Born DE, Doyle DL, et al. Progression from frontal-parietal to mesial-temporal epilepsy after fluid percussion injury in the rat. Brain (2005) 128(Pt. 1):174-88. doi:10.1093/ brain/awh337

46. Fox JL, Vu EN, Doyle-Waters M, Brubacher JR, Abu-Laban R, Hu Z. Prophylactic hypothermia for traumatic brain injury: a quantitative systematic review. CJEM (2010) 12:355-64.

47. Polderman KH. Induced hypothermia and fever control for prevention and treatment of neurological injuries. Lancet (2008) 371(9628):1955-69. doi:10.1016/S0140-6736(08)60837-5

48. Jiang JY, Xu W, Li WP, Gao GY, Bao YH, Liang YM, et al. Effect of longterm mild hypothermia or short-term mild hypothermia on outcome of patients with severe traumatic brain injury. J Cereb Blood Flow Metab (2006) 26(6):771-6. doi:10.1038/sj.jcbfm. 9600253

49. Sadaka F, Veremakis C. Therapeutic hypothermia for the management of intracranial hypertension in severe traumatic brain injury: a systematic review. Brain Inj (2012) 26(7-8):899-908. doi:10.3109/02699052.2012.661120

50. Sayeed I, Stein DG. Progesterone as a neuroprotective factor in traumatic and ischemic brain injury. Prog Brain Res (2009) 175:219-37. doi:10.1016/ S0079-6123(09)17515-5

51. Wright DW, Kellermann AL, Hertzberg VS, Clark PL, Frankel M, Goldstein FC, et al. ProTECT: a randomized clinical trial of progesterone for acute traumatic brain injury. Ann Emerg Med (2007) 49(4):391-402. doi:10.1016/j. annemergmed.2006.07.932

52. Xiao G, Wei J, Yan W, Wang W, Lu Z. Improved outcomes from the administration of progesterone for patients with acute severe traumatic brain injury: a randomized controlled trial. Crit Care (2008) 12(2):R61. doi:10.1186/cc6887

53. Stein DG, Sayeed I. Is progesterone worth consideration as a treatment for brain injury? Am J Roentgenol (2010) 194(1):20-2. doi:10.2214/AJR.09.3407

Conflict of Interest Statement: The authors declare that the research was conducted in the absence of any commercial or financial relationships that could be construed as a potential conflict of interest.

Copyright $\odot 2016$ Kirmani, Robinson, Fonkem, Graf and Huang. This is an open-access article distributed under the terms of the Creative Commons Attribution License (CC BY). The use, distribution or reproduction in other forums is permitted, provided the original author(s) or licensor are credited and that the original publication in this journal is cited, in accordance with accepted academic practice. No use, distribution or reproduction is permitted which does not comply with these terms. 